\title{
Remote Placental Infarction
}

National Cancer Institute

\section{Source}

National Cancer Institute. Remote Placental Infarction. NCI Thesaurus. Code C117322.

A focus of necrotic placental parenchyma with marked hyalinization and fibrosis with complete absence of the necrotic chorionic villi, which is frequently more than 7 days of duration. 